\title{
Perceptions with Non-English Educational Background Competence in English Teaching
}

\author{
Andi Mukarramah Nagauleng', Andi Asrifan², Ahmad Mustamir Waris3
}

DOI: 10.35445/alishlah.v13i2.839

\begin{abstract}
Article Info
Abstract

Keywords:

Teacher skills;

Non-English teacher

background;

English teaching

This research's purposes were: (1) exploring the perceptions of non-English teachers in teaching English at IAIN Manado; (2) assessing the ability of nonEnglish teachers to attain IAIN Manado student qualifications. This study uses a mixed research method based on an exploratory sequence. The research was conducted using IAIN Manado Purposive sampling technique, and the researcher determined the research object by specific criteria. The study results show: (1) They loved how a non-English professor teaches English. They say that if a non-English teacher is amiable in teaching, he often motivates students to learn English. They also value non-English-based lecturers. Students also actively follow teaching and learning activities, (2) Student evaluations also were found in pre-test and post-test data when post-test ratings were increased, with $7(41.17 \%)$ having an average value, $5(29.42 \%)$ with good ratings, 4 (23.0\%) with poor scores, and $1(5.89 \%)$ with very good ratings. This means a significant increase in English language learning by non-English lecturers.
\end{abstract}

Kata kunci:

Keterampilan guru;

Latar belakang

pendidikan dosen non-

bahasa Inggris;

Pengajaran bahasa

Inggris

\begin{abstract}
Abstrak
Tujuan dari penelitian ini adalah: (1) untuk mengetahui persepsi dosen nonBahasa Inggris dalam mengajar bahasa Inggris di IAIN Manado; (2) menilai kemampuan Dosen non bahasa Inggris untuk mencapai kualifikasi mahasiswa IAIN Manado. Penelitian ini menggunakan metode penelitian campuran berdasarkan urutan eksploratif. Penelitian dilakukan dengan menggunakan teknik Purposive Sampling IAIN Manado, dan peneliti menentukan objek penelitian dengan kriteria tertentu. Hasil penelitian menunjukkan: (1) Mahasiswa menyukai bagaimana seorang dosen non-Inggris mengajar bahasa Inggris. Mereka mengatakan bahwa jika dosen non-Inggris sangat ramah dalam mengajar, ia sering memotivasi siswa untuk belajar bahasa Inggris. Mereka juga menghargai dosen non-Inggris. Siswa juga berpartisipasi aktif dalam kegiatan belajar mengajar, (2) Evaluasi siswa juga ditemukan pada data pre-test dan post-test ketika nilai post-test meningkat, dengan $7(41,17 \%)$ memiliki nilai rata-rata, $5(29,42)$. \%) dengan skor baik, $4(23,0 \%)$ dengan skor buruk, dan $1(5,89 \%)$ dengan skor sangat baik. Artinya ada peningkatan yang signifikan dalam pembelajaran bahasa Inggris oleh dosen non-Bahasa Inggris.
\end{abstract}

\footnotetext{
${ }^{1}$ Institut Agama Islam Negeri Manado, Sulawesi Utara, Indonesia Email: Andi.mukarramah@iain-manado.ac.id 2 Universitas Muhammadiyah Sidenreng Rappang, Sulawesi Selatan, Indonesia Email: andiasrifan@gmail.com 3 Institut Agama Islam Negeri Manado, Sulawesi Utara, Indonesia Email: ahmadmustamirwaris@iain-manado.ac.id
} 


\section{INTRODUCTION}

The learning process cannot be carried out without a lecturer supporting an educational institution. Lecturers must start managing lessons, determining learning materials, formulating learning goals, and learning goals using defined methods to evaluate learning and other professional skills. Even crucial elements have to be owned by a teacher if the role or ability influences the success of an educational program. A teacher must also have pedagogical knowledge when applying the teaching to students to make a significant difference to student learning (Gibbons \& Cobb, 2017; Patton \& Parker, 2017).

Personal, technological, scientific, spiritual, and social skills combine professor skills and become a holistic professional. These skills are composed of mastery of the material, education, student knowledge, attitudes and self-development in such a way that they follow a national policy outlined in the explanation of Government Regulation No. 19 of 2005 relating to national educational standards, namely pedagogical, personal, social and professional skills (Musfah, 2011).

Pedagogical skills are one aspect of determining learning success in particular subjects or study areas. Mulyasa (2009) and Soepriyatna (2012) mean teachers' ability to manage learning activities is pedagogical. This learning involves learners understanding, building and implementing learning designs, evaluating learning outcomes, and developing students' knowledge and attitudes to update their various potential skills. Dardjowidjojo says that personal, social, and professional skills support pedagogical skills. These skills directly and cumulatively affect student behavior, learning habits, the desire to learn, and motivation and discipline. Knowledge, abilities, and attitudes are the meaning of personality here (Rusitayanti, 2021). The characters shown by the teacher during the learning process are always seen, observed, and measured by the students (Bahruddin, 2018; Mudlofir, 2021).

Teacher and lecturer career is the professional field of practice carried out by teachers and lecturers in compliance with Article 7 of Indonesia's Constitution No 14 of 2005: b) dedication to bettering education quality, devotion to the faith and nobility; thus, teaching skills are a vital component of teaching and learning, with a variety of responsibilities, not only a "readers" who provide the expertise they need but also as teaching guides to encourage students to create alternatives and to inspire students. Therefore, teachers must master scientific teaching and have the knowledge and technical skills and human, social and professional abilities to achieve learning goals and complicated tasks.

It was found that lecturers who already had education certificates had no teaching competence (Hadi et al., 2018). Some teachers may find it hard to implement the material they master for students, as teachers lack training facilities. All educational institutions in Indonesia must implement educational programs. This does not mean teachers are not professional in teaching, but they doubt the pedagogical skills they teach in their study field. Low teacher expertise affects reduced student performance (Anwar, 2007; Rinantanti et al., 2017).

As English teachers fail (Malik et al., 2021; Mudra, 2018; Ratminingsih, 2021; Senjahari et al., 2021), EFL is considered unsatisfactory as not meeting the criteria for French. Teachers require extraordinary personal skills as well as teaching and learning skills. Personal skills decide whether future students, particularly poor English and English, are successful instructors, educators, or trainers.

Excellent English speakers with an English course background are common occupations. However, an extraordinary English teacher is extraordinary without an English course. It will certainly be an interesting phenomenon, as a particular case study deserves everyone's attention. It is clear from all the research results in this area that, although non-English education lecturers are vital in teaching English, they focus only on the ability of an English teacher or teacher with an English education background. It will undoubtedly pose a new problem in assessing research teachers' abilities instead of their educational background, which is sometimes better qualified than teachers. 
While students respond positively to non-English teachers, it does not mean that teachers have professional teaching skills. There must have been many factors to this phenomenon. Therefore, the researchers intend to use a mixed-method design to relate the findings to students' views and their performance in English to investigate and study this situation.

Based on observations at IAIN Manado in June 2020. In the observations of teaching English in the classroom, the researcher found an interesting phenomenon when the non-English lecturer taught English subjects fluently, interactive, and communicative. It turned out that he is learning English. He completed his undergraduate education from Al-Azhar University in Cairo, and he completed his master's degree from Australia and his doctorate from the United States. The researcher also interviewed several students and lecturers to confirm the case and discover their perception of non-English educational background competencies in teaching English. Most of their responses were positive towards lecturers with non-English educational background competencies in teaching English.

Akhyak (2013) conducted research entitled "Implementation of Teachers Pedagogy Competence to Optimizing Learners Development in Public Primary School in Indonesia." The study results indicate that the four aspects of teacher competence must be considered in conducting teacher competency research. A recent study will explore four aspects of the competence of lecturers with non-English educational backgrounds. Aziz and Akhtar (2014) highlighted teachers' experiences through a survey study entitled "Impact of Training on Teachers Competencies at Higher Education Level in Pakistan" to compare teachers' competencies with no training experience. This study suggests that this type of training program be continued to improve teacher competence, and a teacher competency study should be conducted to identify the urgent needs of teachers and prepare programs to facilitate their needs.

The study on teacher competence at higher education level was also conducted by Yüksel (2014) in her research entitled "Teachers of the Future: Perceived Teaching Competencies and Visions of Pre-service English Language Teachers." If Azis\&Akhtar's study focuses on teacher competence in general by applying a survey research approach, Yüksel, on the other hand, focuses her study on the competence of EFL teachers through a convergent parallel mixed methods research design. Her study investigated how the 40 pre-service teachers of EFL in Turkey assessed their teaching competencies and how they projected themselves as teachers in the future. The result of the quantitative data revealed that the teacher's perception regarding various teaching competencies was similar, and they felt that they were competent enough in teaching The qualitative data indicated that the participants would possibly apply the constructivist approach to language teaching. The findings suggest that participants developed their professionalism by keeping up with the changes and innovations while teaching.

Other researchers, e.g. Richard (2011) in his article entitled "Exploring Teacher Competence in Language Teaching," stated that any attempt to characterize the nature of quality, proficiency, professionalism, or effectiveness in language teaching is liable to the charge of different kinds of bias since it is bound to reflect understandings that are shaped by culture, by context, by individual belief and preference as well as by limitations in our present state of knowledge. It is in line with what was stated by Rinantanti (2017) in their research entitled "Multilingual Lecturers' Competence in English Teaching at the University of Iqra Buru, Indonesia," they found that 1) the multilingual lecturers have high competence in personal and social, while their excellent intercultural and emotional competence has reinforced the lack of their pedagogical and professional competence; 2) the main factors that influenced the multilingual lecturers' competence were educational background, experiences, social interactions, and cross-cultural communication; and 3) the students mainly evoked positive perception toward the multilingual lecturers' competence in English teaching. Rinantanti (2017), who conducted other research entitled "Perception of Senior High School EFL Teachers in Papua, Indonesia towards their Competence", found that the EFL teachers perceived 
their competence as good. None of the respondents asserted either they have poor or fairly good competence.

The research findings are related to recent teacher/lecturer competencies, perceptions, and measurements of experienced and inexperienced teachers. Most of them still focus on the competence of EFL lecturers in teaching English and consider it an ordinary profession based on their expertise, except for Bin-Tahir \& Rinantanti, who explores the competence of non-English lecturers through the competence of multilingual lecturers. This latest research is different from research on lecturers with non-English educational backgrounds in teaching English competence, focusing on one informant to study more deeply, and using research methods, namely, mixed methods research consisting of case studies. Design and experimentation through one group pretestposttest design. Moreover, the research location takes in IAIN Manado.

\section{METHODS}

This study used a sequential research design of mixed methods, a two-phase data collection design. The two phases began collecting qualitative data and continued collecting quantitative data, analyzing both. This collection is made to develop surveys to enable classification to develop data testing or variables. This testing and identification use information obtained from a diary or a relevant research development journal, given a large sample as an example for this study (Creswell \& Clark, 2017; Creswell \& Creswell, 2017).

Qualitative research in the study focuses on case studies, namely in-depth studies on individuals and social groups. All the variables that are essential for the development of the subject are identified. This research is based on a detailed study in which the researcher collects data on recent phenomena, experiences, observational sites, and how such factors can be connected.

Naturalistic methods are also conducted to facilitate case studies to help in this study by observing natural conditions. This case study is the same as the ethnographic approach commonly used in cultural anthropology, also known as a qualitative approach. This case study was carried out because the data were not produced, and there was no effect of object dynamics on the researcher's existence.

Furthermore, researchers used a one-group post-test design experiment to obtain data on student achievement in this quantitative study. That is, quantitative data are used to reinforce qualitative data.

The research was conducted in the Department of Education, the Faculty of Tarbiyah, Islamic State Institute, Manado, from June until August 2020. The key source of variables analyzed was the informant. The informant was a teacher who taught English from the English department. The atmosphere from which the teacher teaches English provided secondary data sources. These data were gathered from observations and interviews with some teachers, students, and study papers in the English department.

The informant was determined utilizing purposeful sampling. The investigator was identified by researchers directly using basic study parameters, collected through preliminary observations and interviews on the field (Ramadass \& Aruni, 2019; Sugiono, 2005; Vijayalakshmi \& Sivapragasam, 2019). A professor, English-skilled and English experts were the criteria of the informant.

The qualitative data analysis technique uses the path proposed by Milesand Huberman (1994) that there must be three simultaneous actions: a) data reduction, b) presentation of data, and c) concluding/verification.

The study's quantitative data were analyzed using the SPSS Version 25 program to see quantitative data on students' English test results before and after learning English taught by lecturers with non-English educational backgrounds. Researchers have calculated scores descriptively and compared the average student achievement score on the pre-test and post-test to see the difference in scores on the pre-test and post-test. 
This study focused on teaching skills. The researchers concentrated on the pedagogical abilities of non-English teachers for a non-English instructor to enhance his English. The teacher's capacity to prepare and execute the training program, diagnose student barriers and learning issues, develop learning programs, and improve teaching responses as non-English teachers to improve English learning performance within the Manado Department of IAIN.

\section{FINDINGS AND DISCUSSION}

\section{The students' perceptions of English teachers with non-English Educational Background Competencies}

In this study, it seems that students are interested in and appreciate the non-English teacher method. The students were happy to attend the lecture because of the lecturer's kindness, particularly the teacher's positive motivation.

While the student's distrust was due to its relatively low level of English, the non-English teacher did give the students an unforgettable pleasure.

The class was divided into three different groups.

Group 1 said:

"Belum adanya rasa percaya diri pada kami, kemampuan bahasa Inggris kami belum sebaik yang lain yang berasal dari jurusan bahasa Inggris."

"Our English language skills are not as good as other English languages."

The statement is then similar to the statements made by groups 2 and 3 .

"Tidak, belum ada rasa percaya diri pada kami karena kami rasa kosakata yang kami miliki masih sedikit dalam berkomunikasi."

"No, there is still no trust in us because we think we have a small vocabulary to communicate."

Group three said:

"Belum, keterampilan kita belum mancapai arah sana. Butug proses untuk bisa menigkatkan lagi Keterampilan kita dalam komunikasi dan penguasaan bahasa Inggris kita, selain itu mungkin juga harus adanya pengambilan kelas khusus dari kita, misal kursus bahasa Inggris, agar muncul rasa percaya diri dengan kemampuan komunikasi kita. Iya .. intinya pada keseluruhan itu dibutuhkan proses lenih lanjut”.

"No, our skills have not yet gone that way. There is a process to improve our communication skills and our mastery of English, and a special class may also take us, for instance, to enable trust in our communication skills. Yes .. Yes.. The point is that it needs further processing in general."

Even with the students who love the teacher. After the non-English lecturer gave the material, almost all the English scores of the students increased at examination time. It is only that, although the lecturer has shown positive motivation, the students have not developed confidence in using their English. What happens in campus lectures, particularly faculties, is not supported by regulations leading to English, namely an obligation to use English for students when entering the field of English.

\section{The significance of a non-English lecturer is consistent with English learning goals}

Researchers selected Seventeen students from the Tarbiyah Faculty who studied English from non-English teachers for the 2019-2020 period. The researcher includes preliminary, primary and operational trials of the student's achievements in English. 
Tabel 1. Pre-test Frequency and Percentage

\begin{tabular}{lccc}
\hline \multicolumn{1}{c}{ Classification } & Score & F & P (\%) \\
\hline Excellent & $86-100$ & 0 & $0 \%$ \\
Good & $76-85$ & 0 & $0 \%$ \\
Average & $66-75$ & 0 & $0 \%$ \\
Poor & $56-65$ & 0 & $0 \%$ \\
Very Poor & $<55$ & 17 & $100 \%$ \\
& & & \\
\hline & & 17 & $100 \%$ \\
\hline
\end{tabular}

Test results for the students were scarce. The data showed that students are classified as the lowest to know that students lacked English skills during pre-implementation. (The data was taken on 14 June 2020).

Tabel 2. Post-test Frequency and Percentage

\begin{tabular}{lccc}
\hline \multicolumn{1}{c}{ Classification } & Score & F & P (\%) \\
\hline Excellent & & & \\
Good & $86-100$ & 1 & $5.89 \%$ \\
Average & $76-85$ & 5 & $29.42 \%$ \\
Poor & $66-75$ & 7 & $41.17 \%$ \\
Very Poor & $56-65$ & 4 & $23.50 \%$ \\
& $<55$ & 0 & $0 \%$ \\
\hline \multicolumn{2}{r}{} & & \\
\hline
\end{tabular}

Test results for the students were scarce. The data showed that students are classified as the lowest to know that students lacked English skills during pre-implementation. (The data was taken on 14 August 2020).

Table 3. Students at Pretest and Posttest

\begin{tabular}{ccc}
\hline & Pretest & Post-test \\
\hline $\mathbf{N}$ & 17 & 17 \\
Mean & 40.29 & 74.11 \\
Std. Deviation & 8.564 & 9.054 \\
\hline
\end{tabular}

Students ' standards differed before studying with non-English teachers; students got an average score after learning from their teachers. It means that non-English lecturers can learn more English. Therefore, the researchers have concluded that non-English teachers will enhance students' ability to speak English and achieve learning objectives.

\section{The perceptions of the students towards teachers with a non-English background}

Undergraduate teachers have shown that they can teach English to students without primary non-English education. Students are loved, and students respect their teachers, and the truth is that teachers are helpful and friendly. The teacher listened to the student's grievances, mainly because he was learning English.

Group II said that if they praised non-English teachers for their friendliness, they never saw the teachers' anger and felt that non-English teachers were highly open to their students who have always been trying to help them with English issues.

"Kami sangat memuji bapak yang mengajarkan bahasa Inggris kepada kami, kami sangat menghargai beliau meskipun kami belum melihat bapak marah. Dan Kami sangat menikmati saat mengikuti pengajaran yang dibawa oleh bapak, kami sering disambut, tidak pernh marah, tidak adanya paksaan kepada kami untuk menyelesaikan tugas bahasa Inggris yang menurut kami rumit, bahkan kami sampai diajak untuk masuk bersama ke kelas, sehingga dalam pelajaran bahasa Inggris kami mampu untuk memahaminya". 
"We praise you who taught us English; we appreciate him even though we haven't seen you angry. And we enjoyed attending the teaching brought by the father, we were often greeted, never angry, there was no pressure on us to complete English assignments which we thought were complicated, even we were invited to come together to class, so in English lessons, we were able to understand it". (Interview with group II)

This perception influences behavior in keeping with Atweh A and Warbuton A, where an individual perceives a basis when he shows his response to an event or behavior of a person (Atweh et al., 1998; Warburton, 2004) If non-English teachers teach, students are active in following it because they have a passion for teaching teachers, despite other teachers' other work.

Their perceptions give scope for private ways of responding to data. Perception is related to interpretations, introduction, and understanding of an object, event, or sensory stimulation, such as listening, smelling, touching, or feeling. Perception allows us to obtain and make sense of sensory information to know that perception is using sensory information from the environment or that it can also interact with the environment (Robin et al., 2003).

There is just a lack of self-confidence about their ability to speak English, even though their ability can be improved. Disgrace, fear that they are wrong, and feel that they are not often haunting their minds in their direction. However, they agreed to continue studying it to improve their English skills.

Although non-English teachers always motivate their students to be confident in their English skills while teaching, they feel pessimistic. This is demonstrated by the three statements of the group after the interview. Some factors lie in the perceiver, the perceived object and target, and the context and situation of the perceptive act deriving from the five senses. The interpretation of one who sees and elevates interpretation, for example, results in a perception that influences the individual's characteristics. The suitability of the individual properties of the one perceives and influences the perception starting from motifs, attitudes, expectations, experiences, and objects given to the perception. Meanwhile, people observe objects that become essential things from the job to the social environment.

The researcher found that students were pleased with not English lecturers 'teaching method with their enthusiasm constantly entering the lecturer's course. Students respect non-English lecturers; after the instruction of those non-English lecturers, they feel their English skills have improved. It is only that they are still embarrassed to use their English; one of them is not confident for several reasons.

Edwards says that (Edwards, 2014), on average, amateurism is understood as a form of denigrating. It can also be the idea of activity "for one's love," besides that if the individual does not meet a formal requirement. There are also problems between workers and a range of working relationships based on different skills and concepts.

Because of Edward's opinion, we can know that no matter how hard our activities or work are, following the direction we have now about wrong perceptions, we only cause professionals' unprofessional jobs in their fields and experts.

\section{The significance of a non-English-speaking lecturer reaches English-speaking goals}

The researcher found that many students were able to learn English from teaching good grades to non-English teachers. The pre-test and post-test data collection showed that the average pre-test score rose to 40.29 and a post-test to 74.11.

Student evaluations also were found in pre-testation and post-statement data when post-state ratings were increased, with 7 (41.17\%) having an average value, 5 (29.42\%) with good ratings, 4 (23.0\%) with poor scores, and 1 (5.89\%) with very good ratings. This means a significant increase in English language learning by non-English lecturers.

Nevertheless, students still find it challenging to express thoughts and interpret the meaning of the questioner. This happens because the interactive interpreting process requires a method of 
producing, receiving, and processing information. The factors start from the individual, the physical environment, collective experience, purpose, and language acceptance.

The students' common vocabulary is an essential obstacle because of the influence of their first language. Accordingly, increased student activities, from dialogue, speech-related games, questions and answers, and teacher monologues call for problems for students such as poor vocabulary and mother tongue skills.

It can also be seen that non-English lecturers' general skills and strategies are sufficient and can be considered in the relevant lecturer category. According to Harmer (2008), adequate and exciting language information and knowledge are needed for proper language teaching. The instructor must also have great enthusiasm and enthusiasm and explain the effective use of language, such as those who teach. He believes that a good language teacher must acquire "a competent attitude that will be prepared for a degree at TESL" plus a good sense of work." Shulman, (1987) and Kral (1988) emphasize reflecting on his teaching in a teacher's interests. Shulman points out that by review, analyze and draft a profession, the teacher must refocus on the process of teaching and training," Different research involves various aspects of teaching, such as providing an environment where students can relax learning and grow well, guiding students, organizing, explaining and explaining, generating and maintaining interest, encouraging students to act actively to discourage them, etc. (Brown, 1994; Tsui, 2003). All this is designed to maintain classroom management and form a learning environment where students and teachers are stress-free by reducing emotional filters and increasing motivation. An environment without stress can give the teacher a sense of volunteerism, eliminating or minimizing the fear of mistakes. (Boon, 2011; Kral, 1988; Shulman, 1987).

IAIN Manado teachers with non-English backgrounds have developed English skills such as self-study (self-taught). Read more magazines and papers, view news on social media, use radio news, even read English-focused songs. These lecturers come from Cairo University, where British Council's English course was given. He then received a Master's degree in Australia. Although management education was considered a major, it was due to Australia's student exchange. Because he had to master English, he studied English beforehand. In addition, non-English teachers directly write and publish English newspapers in international and national newspapers. They are linked to mastering more English and always working with English teachers. Non-English teachers are also often used to examine English students. The speech and essay were also written in English. To maintain English skills, non-English teachers always learn English by teaching English.

Professors with non-English backgrounds will always train their skills through teaching, personal, social, and professional understanding). (Cripps Clark \& Walsh, 2002). The lecturer continues to teach English professionally, understand the teaching material, and run these courses well to train UIN Alauddin Makassar teachers not educated in English. The researchers found that the observations showed that the lecturer always prepared the material during the teaching process. In addition, students are still motivated to study, improve their knowledge, show a good attitude towards students, and talk about good things in class. Even in the course of teaching, the latest technology continuously improves the progress of teaching.(Borg, 2006; Cheung, 2006; Shishavan \& Sadeghi, 2009; Taneri, 2018) Non-English lecturers often participate in English learning seminars to improve their teaching skills. With so much knowledge from this work, they gain and improve their teaching skills. In addition, there is also a brainstorming process with lecturers in the English department. Other people around him are involved in communicating in everyday social life.

Based on the data, the respondents said that if a non-English teacher is teaching friendly, he often motivates students to learn English. They value non-English-based lecturers. Students also actively pursue teaching and learning. Students' English skills also increased after being taught by a non-English teacher. Although grades and abilities of students have improved after being taught by 
non-English teachers, students still lack the confidence to use their English skills. English students are embarrassed as they aren't English majors.

Based on the discussion, the researcher concluded that a non-English teacher could improve English skills for students. Non-English teachers can teach English materials to facilitate understanding. The post-test result is visible, which increases with the pre-test result.

\section{CONCLUSION}

They loved how non-English professors teach English based on the students' perceptions of IAIN Manado's non-English background lecturer in English teaching. They say that if a non-English teacher is very friendly, he often motivates students to learn English. They also value non-Englishbased lecturers. Students also actively follow teaching and learning activities. Students' English skills also increased after being taught by a non-English teacher. Student evaluations also were found in pre-testation and post-statement data when post-state ratings were increased, with 7 (41.17\%) having an average value, 5 (29.42\%) with good ratings, 4 (23.0\%) with poor scores, and 1 (5.89\%) with very good ratings. It means a significant increase in English language learning by non-English lecturers. Although grades and abilities have improved after being taught by non-English teachers, students still lack the confidence to use their English skills. English students are embarrassed as they aren't English majors.

\section{REFERENCES}

Akhyak, M. A. (2013). Implementation of teachers pedagogy competence to optimizing learners development in public primary school in Indonesia. Journal Education and Research, 1(9), $113-122$.

Anwar, S. (2007). Kompetensi Guru Madrasah, Balai Penelitian dan Pengembangan Agama.

Atweh, B., Bleicher, R. E., \& Cooper, T. J. (1998). The construction of the social context of mathematics classrooms: A sociolinguistic analysis. Journal for Research in Mathematics Education, 63-82.

Aziz, F., \& Akhtar, M. M. S. (2014). Impact of training on teachers competencies at higher education level in Pakistan. Researchers World, 5(1).

Bahruddin, B. (2018). Dampak Pembelajaran Eksperimen Kimia Terhadap Minat dan Hasil Belajar Siswa. Andragogi: Jurnal Diklat Teknis Pendidikan Dan Keagamaan, 6(1), 19-40.

Boon, A. (2011). The reflective teacher: Towards self-actualization. The Language Teacher, 35(4), 27-30.

Borg, S. (2006). Teacher Cognition and Language Education: Research and Practice. Continuum.

Brown, H. D. (1994). Principles of language learning and teaching. Pearson.

Cheung, H. Y. (2006). The measurement of teacher efficacy: Hong Kong primary in-service teachers. Journal of Education for Teaching: International Research and Pedagogy, 32(4), 435-451.

Creswell, J. W., \& Clark, V. L. P. (2017). Designing and conducting mixed methods research. Sage publications.

Creswell, J. W., \& Creswell, J. D. (2017). Research design: Qualitative, quantitative, and mixed methods approaches. Sage publications.

Cripps Clark, J., \& Walsh, J. (2002). Elements of a model of effective teachers. AARE 2002: Problematic Futures: Educational Research in an Era of Uncertainty; AARE 2002 Conference Papers.

Edwards, R. (2014). Amateurism and professionalism in work and learning. Journal of Workplace Learning, 26(6/7), 406-417.

Gibbons, L. K., \& Cobb, P. (2017). Focusing on teacher learning opportunities to identify potentially productive coaching activities. Journal of Teacher Education, 68(4), 411-425.

Hadi, R. I., Suhirwan, S., \& Simatupang, H. (2018). Implementasi Undang-Undang Republik Indonesia Nomor 14 Tahun 2005 Tentang Guru Dan Dosen (Studi Kasus Kompetensi Tenaga Pendidik di Wing Pendidikan Teknik dan Pembekalan Kalijati Dalam Mempersiapkan Sumber Daya Manusia Pertahanan TNI AU Tahun 2017). Strategi Pertahanan Udara, 4(3).

Harmer, J. (2008). How to teach English. Longman.

Kral, T. J. (1988). Life-saving techniques for the foreign language learner lost at sea. English Teaching Forum, 26(6-14). 
Malik, S., Qin, H., Oteir, I., \& Soomro, M. A. (2021). Detecting Perceived Barriers in FLSA: The SocioPsycholinguistic Study of EFL University Learners. Advances in Language and Literary Studies, 12(1), 34-45.

Mudlofir, H. A. (2021). Desain Pembelajaran Inovatif: dari Teori ke Praktik. RajaGrafindo Persada.

Mudra, H. (2018). Pre-Service EFL Teachers' Experiences in Teaching Practicum in Rural Schools in Indonesia. Qualitative Report, 23(2).

Mulyasa, E. (2009). Standar Kompetensi dan Sertifikasi Guru. Remaja Rosdakarya.

Musfah, J. (2011). Peningkatan Kompetensi Guru: Melalui Pelatihan dan Sumber Belajar Teori dan Praktek. Kencana.

Patton, K., \& Parker, M. (2017). Teacher education communities of practice: More than a culture of collaboration. Teaching and Teacher Education, 67, 351-360.

Ramadass, P., \& Aruni, A. W. (2019). Research and writing across the disciplines. MJP Publisher.

Ratminingsih, N. M. (2021). Metode dan Strategi Pembelajaran Bahasa Inggris. RajaGrafindo Persada.

Richard. (2011). Exploring teacher competence in language teaching. LANGUAGE TEACHER, 35(4).

Rinantanti, Y., Rahman, M. A., Atmowardoyo, H., \& Bin-Tahir, S. Z. (2017). Perception of Senior High School EFL Teachers in Papua, Indonesia towards Their Own Competence. Journal of Language Teaching and Research, 8(6), 1181-1189.

Robin, A. C., Reylé, C., Derriere, S., \& Picaud, S. (2003). A synthetic view on structure and evolution of the Milky Way. Astronomy \& Astrophysics, 409(2), 523-540.

Rusitayanti, N. W. A. (2021). Kompetensi Profesional Dosen Prodi Pendidikan Jasmani Kesehatan dan Rekreasi Fakultas Keguruan dan Ilmu Kependidikan Universitas Mahadewa Indonesia. Widyadari: Jurnal Pendidikan, 22(1), 127-142.

Senjahari, B., Desfitranita, D., \& Kustati, M. (2021). Learning objectives and environments: How do they affect students motivation in English language learning? Studies in English Language and Education, 8(2), 492-507.

Shishavan, H. B., \& Sadeghi, K. (2009). Characteristics of an effective English language teacher as perceived by Iranian teachers and learners of English. English Language Teaching, 2(4), 130143.

Shulman, L. S. (1987). Knowledge and teaching: Foundations of the new reform. Harvard Educational Review, 57, 1-22.

Soepriyatna. (2012). Investigating and Assessing Competence of High School Teacers of English in Indonesia. Malaysian Journal of ELT Research, 8(2), 38-49.

Sugiono. (2005). Metode Penelitian Pendidikan: Pendekatan Kuantitatif, kualitatif dan R\&D. Alfbeta.

Taneri, A. (2018). Osmanlı Devletïnin Kuruluş Döneminde Hükümdarlık Kurumunun Gelişmesi ve Saray Hayat.

Tsui, A. B. M. (2003). Understanding expertise in teaching: Case studies of ESL teachers. Cambridge University Press.

Vijayalakshmi, G., \& Sivapragasam, C. (2019). Research methods tips and techniques. MJP Publisher.

Warburton, E. C. (2004). Knowing what it takes: the effect of perceived learner advantages on dance teachers' use of critical- thinking activities. Research in Dance Education, 5(1), 69-82.

Yüksel, H. G. (2014). Teachers of the future: Perceived teaching competences and visions of preservice English language teachers. Journal of Human Sciences, 11(2), 27-39. 